\title{
KONSTRUKSI RUANG KOTA POSKOLONIAL DAN RESPONS SPASIAL DALAM NOVEL THE KITE RUNNER KARYA KHALED HOSSEINI
}

\author{
Shabrina An Adzhani \\ Sastra Inggris, Universitas Brawijaya \\ Jln. Veteran Malang, Jawa Timur
}

\begin{abstract}
Abstrak
Migrasi pada masa perang sering kali terjadi dari daerah yang rawan konflik menuju daerah yang dianggap aman dan menjanjikan kehidupan yang lebih baik, merujuk ke kota dan daerah-daerah industri. Namun, keberadaan kota sebagai ruang yang menjanjikan tersebut patut dipertanyakan. Hal ini karena eratnya kaitan antara ruang kota utopia dan kota kolonial. Pada kenyataannya, terdapat indikasi keberlangsungan kontrol kolonial melalui industrialisasi, sehingga memunculkan dominasi baik secara ekonomi, kultural, maupun sosial. Salah satu novel poskolonial karya sastrawan diaspora Amerika-Afganistan, Khaled Hosseini, mengangkat tema perpindahan dari Afganistan yang rawan konflik ke kota yang lebih maju dan lebih aman di Amerika, kota Fremont. Pembacaan politik spasial Sara Upstone dalam hal ini digunakan untuk membaca bagaimana ruang kota Fremont dikonstruksi dan respon spasial yang muncul. Utopia yang digaungkan untuk menarik migran Afganistan terbentur oleh distopia yang dimunculkan dalam ruang kota sejak awal, sehingga dapat disimpulkan bahwa Khaled Hosseini mengonstruksi ruang kota yang menolak utopia. Kota menjadi ruang yang opresif sehingga muncul respon spasial berupa pemindahan dan karnivalisasi dari subjek teropresi sebagai usaha resistensi mereka.
\end{abstract}

Kata kunci: Ruang Kota, Poskolonial, Respon Spasial

\section{Abstract}

In the time of war, people usually migrate from troubled places to the safe and sound cities, promising a better life. However, the position of cities as a promising space is questionable. It is due to the close relation between city utopia and colonial city. In fact, there are indications of colonial continuation through industrialization which ends up to domination in many aspects; economy, social, and cultural. One of postcolonial novels written by a diaspora writer, Khaled Hosseini, takes up a theme of migration from a city (Kabul) in a troubled country, Afghanistan, to a city (Fremont) in a more stable country, America. Sara Upstone's method of reading on spatial politics in postcolonial novels is used here to read how Fremont is constructed in the novel and the spatial respond occurred. The analysis showed that Khaled Hosseini's construction upon Fremont is that utopia is denied from the beginning of the novel. Fremont becomes oppressive space and yet, it offers possibilities for spatial responds such as displacement and carnivalisation to occur. These are strategies used by those who are subjected to oppression in the city space.

Keywords: City space, postcolonial, spatial respond.

\section{Pendahuluan}

Salah satu dampak perang, baik perang saudara maupun perang antarnegara, adalah meningkatnya angka migrasi. Migrasi yang dilakukan di era perang terjadi dari daerah yang rawan konflik ke daerah yang memiliki pertahanan kuat. Amerika Serikat merupakan salah satu negara dengan jumlah imigran terbanyak (Huthmacher, 1974: 7). Walaupun sebagian besar penduduknya berasal dari Inggris dan negara Eropa lainnya, pendatang dari Asia dan Afrika yang menjadi minoritas di negara ini pun memiliki harapan yang besar ketika mereka bermigrasi. Banyak dari mereka yang menetap dan menjadi warga negara
Amerika sebagai seorang diaspora, yakni seseorang berkewarganegaraan asing yang tinggal di negara lain.

Khaled Hosseini adalah salah satu sastrawan diaspora yang kini menetap di New York. Latar belakangnya sebagai seorang anak Duta Besar Afganistan pada tahun 70-an dan harus mencari suaka politik ke Amerika Serikat saat terjadi pendudukan Rusia atas negara asalnya merupakan salah satu inspirasi dari cerita-cerita yang ditulisnya. Novel The Kite Runner adalah karya pertamanya yang bertemakan diaspora. Novel ini dikatakan sebagai novel poskolonial karena selain merupakan karya seorang penulis diaspora dari 
negara yang pernah dijajah, ia dituliskan dalam bahasa Inggris dengan diaspora sebagai tema besar dalam cerita itu sendiri.

Meskipun latar belakang penulis dan cerita novel sangat kental mengindikasikan bahwa novel tersebut adalah novel poskolonial, tidak ada penelitian yang membahasnya secara khusus dari kacamata poskolonial. Beberapa penelitian yang dilakukan di antaranya melihat novel dari segi multikulturalisme yang menyoroti suku Pashtun dan Hazara di Afganistan, serta keberadaan mereka sebagai salah satu unsur multikulturalisme di Amerika (Mallik, 2010), serta dari sudut sosial yang mengaitkan novel dengan tragedi 9/11 (Anker, 2011). Tema poskolonial seakan terlewatkan karena novel yang dituliskan di Amerika ini menjadikan Fremont, latar belakang utama novel pada masa kini novel itu sendiri, sebagai kota yang memberikan kehidupan baik bagi tokoh-tokoh utamanya, Amir dan Baba. Pada kenyataannya, kota tidak sepenuhnya memberikan kehidupan yang lebih baik bagi para migran. Ayah Hosseini yang dulunya seorang duta besar harus bekerja sebagai pegawai toko, demikian juga ibunya, untuk melanjutkan hidup di Amerika. Degradasi status sosial sebagai seorang imigran diaspora juga muncul dalam novelnya, The Kite Runner. Hal ini menjadi menarik karena tidak ada penelitian sebelumnya yang menyoroti.

Adapun poskolonial sendiri dalam kaitannya dengan sastra diartikan sebagai suatu istilah yang mengacu pada cara pembacaan karya sastra (McLead, 2000: 33). Sara Upstone (2007) dalam bukunya Spatial Politics In The Postcolonial Novel menawarkan sebuah metode kritis dalam membaca novel poskolonial. Ia membaca adanya praktik politik tidak hanya di ruang negara yang menjadikan istilah politik itu sendiri sempit, melainkan juga di ruang-ruang lain yang bisa jadi ruang yang lebih luas maupun ruang yang lebih sempit.

Upstone (2009) mengutip Kate Darian Smith, Liz Gunner, dan Sarah Nuttall, mengatakan bahwa "It is place that holds meaning, while space is simply ... a container". Mengutip definisi Bill Ashcroft mengenai perbedaan tempat dan ruang, Upstone (2009) menjelaskan bahwa tempat menandakan kontrol colonial, sementara ruang merujuk pada hal yang lebih luas dan lentur, bentuk-bentuk yang ingin dikaburkan oleh kolonial. Ruang adalah wadah dalam artian yang abstrak di mana konsepkonsep yang hegemonik dapat ditanamkan karena sifatnya yang lentur.

Ruang dalam wilayah kolonial digunakan untuk mempertahankan stabilitas kolonialisme. Ruang-ruang dengan batas-batas yang ditampakkan sebagai batas natural dikonstruksi oleh orangorang kolonial untuk membedakan mereka dengan pribumi. Dengan menghidupkan dirinya (kehidupan kolonial) di ruang pribumi, batas-batas semakin terlihat dan kekuasaan kolonial tampak absolut, fixed (Upstone, 2009: 4). Undang-undang, agama, pendidikan, dan cara orang-orang kolonial bersosialisasi serta cara hidup mereka terlihat lebih canggih di mata pribumi, sehingga kaum kolonial dianggap superior. Konsep ruang dan batasan-batasan yang ditanamkan oleh kolonial telah mengaburkan preferensi pribumi terhadap apa yang telah ada dalam diri mereka, baik itu identitas maupun praktik-praktik dalam kehidupan yang telah ada sebelum kolonialisme. Imperialisme mengukuhkan kekuasaannya terhadap wilayah teritorial yang kemudian dipetakan sebagai daerahnya, serta menanamkan superioritasnya dalam ruang kekuasaan tersebut, sehingga orangorang pribumi menganggapnya sebagai hal yang wajar (natural).

Teori poskolonial membaca politik ruang kolonial tersebut dan menguraikan apa yang telah dikaburkan. Teks-teks poskolonial mempertanyakan berbagai kemungkinan lain atas tatanan yang ditanamkan oleh kolonialisme. Pembacaan ruang dalam konteks poskolonial memberikan kemungkinan-kemungkinan negosiasi identitas dan kemungkinan resistensi yang ada. Upstone (2009) menawarkan pembacaan pengalaman-pengalaman poskolonial tersebut yang dikonstruksi dalam beberapa ruang, di antaranya ruang negara, ruang perjalanan, ruang kota, ruang rumah, dan ruang tubuh.

\section{Konstruksi Kota dan Respons Spasial}

Kota adalah salah satu ruang alternatif dari negara dengan skala yang lebih kecil di mana 
gerakan-gerakan poskolonial direpresentasikan (Upstone, 2009: 85). Dalam pembacaan pascakolonialnya, Upstone menguraikan jejakjejak kompleksitas hubungan antara pengarang dengan kota dalam hal bagaimana mereka merepresentasikan kota. Pembacaan tersebut berdasar pada kecurigaan bahwa terdapat kesenjangan antara impian akan kota dan realitas yang ada. Selain itu, terdapat ambiguisitas dalam kota di mana kota seakan menawarkan kemungkinan-kemungkinan terrealisasinya utopia, namun mengingat hubungan kota dan negara cukup erat dalam hal politik, keberadaan kota sebagai tempat yang bersahabat dan terbuka bagi individu poskolonial patut dipertanyakan (Upstone, 2009: 85).

Kota seringkali dikaitkan dengan wacana utopia dimana bagi ruang urban kota tidak digambarkan dalam realitas material melainkan sebagai mimpi, tempat imajiner di mana segalanya sempurna. Upstone (2009: 85) melihat kota utopia sebagai ruang yang memproyeksikan keinginan dan harapan komunal, mengesampingkan fakta lain yang juga berkaitan erat dengannya yakni gambaran akan kengerian industrialisasi. Jika kolonialisme mengatur ruang dengan cara terusmenerus menulisinya dengan ide-ide yang dibawa untuk kemudian menghapuskan kekacauan (chaos) yang ada, ide-ide utopia menjadi bentuk kolonisasi laten dimana ia tidak dilihat sebagai hal yang tidak terrealisasi melainkan indikasi adanya keinginankeinginan individu/komunal dan kontrol selanjutnya melalui industrialisasi dan tatanantatanan penguasa di ruang tersebut.

Upstone (2009: 87) memformulasikan tiga bentuk kota poskolonial dari pembacaannya terhadap beberapa novel poskolonial. Pertama, kota yang dikonstruksi dengan menolak keistimewaan kota sebagai ruang kota utopia. Ruang kota ini dikonstruksi dengan menghadirkan distopia sejak awal sehingga terjadi benturan terhadap utopia dan membuatnya tidak mungkin terwujud sepenuhnya. Kedua, kota yang sangat dekat dengan pengertian utopia, sebuah kota yang ideal. Kota ini dikonstruksi dengan memberikan gambaran yang nyata pada pembaca melalui pengambilan referensi dari tempat-tempat yang nyata namun menghilangkan identitas konkretnya dengan tidak menyebutkan nama kota tertentu. Adapun kota yang ketiga tepat mengenai jantung imajiner poskolonial, kota yang mengindikasikan adanya pengulangan tindakan kolonialisme serta perubahan di dalamnya, pengedepanan lapisanlapisan yang chaos yang menjadi dasar yang ingin dikaburkan oleh tatanan kolonial.

Ketiga konstruksi ruang kota tersebut memunculkan distopia sebagai bentuk opresi, namun kemunculannya berbeda-beda. Di kota yang pertama, distopia muncul sejak awal, di kota yang ke dua distopia muncul namun tidak disadari bahkan berusaha untuk disangkal, sementara di kota yang ke tiga, distopia muncul kemudian, ketika konflik di kota poskolonial terjadi. Distopia yang merepresi subjek-subjek kolonial menginisiasi adanya respon spasial, respon di ruang kota sebagai usaha resistansi mereka terhadap hal-hal opresif. Upstone (2009: 103) mengusulkan dua strategi resistensi dan subversi yang menjadi pokok untuk meninjau kembali ruang kota, yaitu pemindahan (displacement) dan karnivalisasi (carnivalisation).

Strategi pertama yang dimaksud oleh Upstone adalah pemindahan rasa memiliki yang berusaha ditumbuhkan para etnis minoritas bukan pada kota secara keseluruhan namun pada bagianbagian yang lebih kecil dalam kota tersebut, seperti tempat-tempat umum, gedung-gedung dalam kota, dan ruang terbuka lainnya yang mengonstruksi kota. Ketika kota menjadi sangat opresif, resistensi muncul dalam relasi-relasi berupa mikro struktur. Relasi mikrostruktur ini bisa berupa ekspresi identitas di ruang publik dan ruang terbuka yang mengonstruksi kota dan hubungan personal misalnya hubungan antartokoh, relasi antarpersonal dalam komunitasnya, bahkan aktivitas individual yang membuat seseorang merasa nyaman dan menjadi dirinya sendiri. Adapun karnivalisasi adalah strategi dimana identitas yang sifatnya tidak teratur (chaos), bybrid yang berusaha dihomogenkan oleh tatanan kolonial, dimunculkan dalam ruang publik (Upstone, 2009: 106).

Masing-masing strategi memiliki kelemahan. Ketika displacement saja yang digunakan, subjek terkoloni justru sebenarnya menjauhkan dirinya dari ruang kota dan membuat ruang 
sendiri yang lebih sempit yang akan membatasi pergerakannya. Ia akan merasa nyaman di ruang sempit tersebut, namun ruang kota secara keseluruhan akan tetap represif baginya. Karnivalisasi sendiri menjadi strategi yang efektif dalam tataran imajiner, tapi pada kenyataannya ia tidak dapat menghindarkan ruang kota yang kacau dari kehancuran sebagaimana kota Jonestown yang menginspirasi novel Jonestown karya Wilson Harris (Upstone, 2009: 107). Strategi yang paling efektif adalah ketika pemindahan dan karnivalisasi dilakukan bersama.

\section{Fremont sebagai Ruang Kota Poskolonial}

Amerika menjadi tujuan bermigrasi sebagian besar orang-orang Afganistan ketika terjadi pendudukan oleh Rusia di negara tersebut. Dalam novel The Kite Runner, diceritakan bahwa Amir, Baba, dan sebagian besar orang Afganistan lainnya harus menunggu selama 6 bulan untuk mendapatkan visa dari INS. Narasi tentang hal tersebut diselipkan Amir ketika ia menceritakan masa-masa penantian pembuatan visa di Peshawar, "We'd spent six months in Peshawar waiting for the INS to issue our visa. .. He'd invited the entire corridor of neighbors for dinner, most of them Afghans waiting for visas"(Hosseini, 2003: 113). Ini menunjukkan bahwa Amir, Baba, dan sebagian orang Afganistan lainnya menjadikan Amerika sebagai tujuan akhir migrasi mereka dengan kota Fremont sebagai kota yang akhirnya menjadi tempat menetap Amir dan Baba.

Fremont, salah satu kota di negara bagian California, Amerika Serikat, merefleksikan ideide utopia Amir dan Baba tentang kota yang memberikan kehidupan yang lebih baik, yakni kebebasan dan ide-ide menakjubkan tentang Amerika semenjak mereka masih berada di Afganistan. Hal ini dapat dilihat dalam narasi novel yang dibawakan oleh tokoh "aku", Amir. Baba, ketika masih berada di Afganistan, sering mengeluhkan Jim Carter sebagai orang yang kurang berani memimpin Amerika, yang dianalogikannya sebagai Cadillac model terbaru. Baba memberikan penilaian yang tinggi terhadap Amerika, yang juga mengimplikasikan bahwa ideide tentang kemegahan, keunggulan, dan berbagai keistimewaan lain dimiliki oleh Amerika. Ketika mereka baru pindah keFremont pun Baba mengeluelukan Amerika sebagai salah satu negara yang bisa disebut sebagai pria sejati di seluruh dunia, "There are only three real men in this world, Amir,... America, the brash savior, Britain, and Israel." (Hosseini, 2003: 109). Ide-ide tersebut mengimplikasikan betapa Baba menganggap Amerika lebih baik bahkan dari Afganistan sendiri.

Amerika yang menjadi tempat Baba membawa Amir mencari ketenangan dari tekanan penjajah Rusia dan ancaman akan peperangan menyuguhkan tatanan baru yang tidak membebaskan dan tidak memberikan ketenangan baginya. Di balik utopia akan Fremont sebagai representasi dari Amerika yang dapat dilihat dari bagaimana Baba mengelu-elukan Amerika sebagai seorang pria sejati, Baba merasa Amerika bukanlah tempat yang bersahabat.

Setelah dua tahun masa tinggal Amir dan Baba di Fremont, Baba belum sepenuhnya menerima kota itu sebagai tempat yang membebaskan ataupun memberikan ketenangan sebagaimana impian utopianya akan kota tersebut. Fremont membebaskannya dari ancaman kematian yang ditimbulkan oleh penjajah Rusia. Dengan meninggalkan Afganistan yang pada saat itu sedang sangat kacau dan tidak aman bagi Baba yang suka mengkritik tentara Rusia, mereka menuju Fremont yang melindungi keselamatan mereka. Di Fremont, Baba bebas mengutarakan pendapat dan kebenciannya pada Rusia tanpa takut terancam dibunuh. Di Fremont pula Baba masuk pada tatanan kota yang opresif bagi jiwanya.

Fremont, Amerika, menjadi tempat di mana Amir menemukan harapan baru, kehidupan baru, dan hal-hal baru lainnya yang sama sekali berbeda dengan masa lalu yang ingin ia lupakan. Amerika masih ia kagumi setelah dua tahun kepindahan mereka dan masih membuatnya takjub akan bentangan kota-kotanya dan alamnya yang kerap dibandingkan dengan Kabul, kota kelahirannya yang memberikan kenangan buruk, bahkan dipenuhi oleh bayangan-bayangan yang menghantui, bayangan orang-orang berbibir sumbing. "Kabul had become a city of ghost for me. A city of harelipped ghosts. America was different. America was 
a river, roaring along, unmindful of the past."(Hosseini, 2003: 119). Hal ini mengimplikasikan harapan personal Amir yang muncul akan kota Fremont, harapan bahwa kota tersebut akan memberinya kebebasan dari bayang-bayang masa lalu.

Pada kenyataannya, utopia Amir akan kota Fremont yang akan memberikannya kehidupan baru, jauh dari bayang-bayang masa lalu, tidak dapat terwujud. Dalam The Family in America, Hawes (1994) menjelaskan pada ulasannya mengenai keluarga imigran, bahwa salah satu kesulitan yang dihadapi oleh para imigran pada pertengahan abad dua puluh adalah kenyataan bahwa mereka harus bekerja dengan jenis pekerjaan yang sangat berbeda dengan yang mereka miliki sebelumnya. Bagi anakanak imigran tentunya hal ini juga berpengaruh ketika mereka mendapati ayah mereka harus melakukan pekerjaan yang dilakukan kalangan kelas menengah ke bawah padahal sebelumnya mereka termasuk golongan menengah ke atas.

Bagi Amir yang terbiasa hidup sebagai kalangan menengah ke atas sejak lahir, kehidupan barunya di kota Fremont sama sekali berbeda. Ia kehilangan status sosial yang dimilikinya ketika di Kabul. Fremont, yang menjadi kota Utopia bagi Amir, menyuguhkan realitas yang harus ia hadapi, bahwa ia harus tinggal di apartemen yang mayoritas penghuninya adalah orang-orang kelas pekerja di lingkungan menegah ke bawah. Ayahnya yang dulu saudagar terkaya di Kabul kini bekerja di pom bensin, dan ia bersekolah di sekolah baru yang mana ia berada di lingkungan yang sama sekali berbeda. Amir tidak pernah secara langsung mengeluhkan penurunan status sosialnya dan Baba. Fremont baginya selalu menjadi kota yang ia impikan, jauh dari Kabul, jauh dari masa lalu. Dari narasinya lah, dan dari cara ia melihat Baba, cara ia menyayangkan keadaan Baba, dan cara ia menggambarkan tempat tinggalnya yang ada di lingkungan pekerja kasar, dapat dilihat bahwa Amir pun secara psikis merasa tidak nyaman dan harus beradaptasi dengan Fremont. Fremont pada kenyataannya tidak menjadi ruang yang merealisasikan harapan utopianya karena harapan tersebut berbenturan dengan realitas yang harus ia hadapi.

\section{Respon Spasial dalam Ruang Kota Fremont}

Fremont menjadi opresif bagi para migran Afganistan dan tokoh utama Amir dan Baba dengan munculnya distopia berupa realitas kota yang berbenturan dengan ide-ide utopia. Namun kota ini juga menawarkan celah bagi individuindividu, yang dalam hal ini merujuk pada Amir dan Baba, serta bagi sekelompok migran Afganistan, untuk melakukan resistensi. Sebagaimana yang ditawarkan oleh Upstone dalam pembacaannya terhadap novel-novel poskolonial, strategi pemindahan dan karnivalisasi pun muncul dalam novel ini. Pemindahan dalam novel The Kite Runner yang hadir dalam bentuk perayaan identitas di ruang publik dapat dilihat dari beberapa data yang merujuk pada kumpulan orang-orang Afganistan di tempat-tempat tertentu yang mengonstruksi ruang kota. Salah satu perayaan identitas Afganistan di ruang publik dimunculkan dengan hadirnya pasar loak yang diikuti oleh orang-orang Afganistan.

"By the summer, Afghan families were working an entire section of the San Jose flea market. Afghan music played in the aisles of the Used Goods section. There was an unspoken code of behavior among Afghans at the flea market: you greeted the guy across the aisle, you invited bim for a bite of potato bolani or a little qabuli, and you chatted. You offered tassali, condolences, for the death of a parent, congratulated the birth of children, and shook your bead mournfully when the conversation turned to Afghanistan and the Roussis - wbich it inevitably did' (Hosseini, 2003: 120).

Fokus rasa memiliki para migran di sini dipindahkan, bukan di kota secara keseluruhan melainkan di pasar loak. Ketika kota menjadi ruang yang opresif bagi para migran yang ditandai dengan munculnya distopia seperti perbedaan budaya yang membatasi ruang gerak mereka, perbedaan bahasa yang juga membatasi pergaulan mereka, dan perbedaan tatanan yang ada di kota, pasar loak di mana orang-orang Afganistan berkumpul menjadi tempat yang nyaman bagi mereka.

Bagi Baba secara pribadi, pasar loak ini juga menjadi ruang publik yang membebaskan dan memberinya titik nyaman ketika ruang kota secara keseluruhan menjadi ruang yang opresif. Baba digambarkan sangat menikmati keberadaannya 
di ruang publik tersebut, "Baba sauntered down the aisles, hands respectfully pressed to his chest, greeting people he knew from Kabul" (Hosseini, 2003: 120). Di sisi lain, Baba tidak melakukan strategi karnivalisasi. Baba tidak bisa menerima perbedaan budaya yang ditandai oleh penolakannya terhadap dokter yang berasal dari Rusia, kekacauan yang terjadi karena ia tersinggung dengan permintaan nyonya Nguyen di toko kelontong, juga terlihat dari interaksi yang dilakukan Baba yang sejauh penggambaran Amir selalu dengan orang Afganistan. Hal ini membuat Baba semakin jauh dari ruang kota dan strategi yang dilakukan, yakni pemindahan, tidak dapat membuatnya resisten terhadap realitas yang ada di ruang kota secara keseluruhan.

Sementara itu, bagi Amir, berada di antara orang Afganistan di pasar loak tersebut mengobati kerinduannya akan masa lalu, tetapi masa lalu yang tidak mencengkeramnya sebagaimana kenangan akan Hassan. Tidak seperti Baba, Amir bersikap lebih cair dan melakukan strategi karnivalisasi dimana ia menerima perbedaan-perbedaan yang mendasari ruang-ruang publik yang mengonstruksi kota. Amir tidak menutup diri pada komunitasnya saja untuk melakukan strategi resistensi akan kota yang opresif, namun ia juga menerima perbedaan, terbuka pada multikulturalisme yang mendasari kota. Ia melihat wacana lintas budaya yang ada di kota sebagai sesuatu yang memberi makna baru pada kota dimana ia tinggal, bahwa mempertahankan homogenitas justru akan membuat ruang kota menjadi semakin opresif.

Bentuk penerimaan Amir terhadap heterogenitas terlihat dalam "carnivalistic contacts and combinations" (Upstone, 2003: 106), interaksi dan kombinasi karnivalistik, antara Amir dan beberapa tokoh yang bukan dari golongan sesamanya, bukan orang-orang yang berasal dari Afganistan, seperti dokter kandungan yang berasal dari Eropa Barat, perwakilan penerbitan dari Amerika Latin, tuan dan nyonya Nguyen pemilik toko kelontong, dan dokter Baba yan berasal dari Rusia.

Tindakan Baba dan Amir yang kontras dalam hal ini merupakan penggambaran yang jelas bahwa ketika strategi karnivalisasi digunakan, subjek-subjek poskolonial dalam ruang kota akan memiliki daya untuk meresistensi opresi di ruang kota. Ketika hanya menggunakan strategi pemindahan sebagaimana yang dilakukan Baba, ruang kota tetap akan menjadi ruang yang opresif karena strategi ini memindahkan titik nyaman seseorang di ruang yang lebih sempit, ruang personal atau ruang publik dimana hanya ada orang-orang yang berasal sama, dalam hal ini berasal dari Afganistan. Namun ketika interaksi Baba dibawa ke ruang terbuka dimana ia bertemu dengan berbagai orang yang berasal dari kultur dan tatanan yang berbeda, kota kembali menjadi ruang yang opresif dan Baba lah yang pada akhirnya akan tersakiti.

\section{Kesimpulan}

Kota kolonial dan utopia kota yang menarik para migran memiliki hubungan yang erat, dimana utopia kota merupakan alat yang menarik orangorang untuk dikoloni oleh tatanan baru. Tatanan baru ini adalah tatanan kolonial di ruang kota, tatanan yang berusaha menghilangkan identitas para migran dengan peraturan dan industrialisasi yang membatasi ruang gerak masyarakat diaspora. Namun, identitas yang dibawa masyarakat diaspora dari daerah asalnya tidak dapat hilang begitu saja. Mereka masih memegang erat identitas dan budaya yang dibawanya sejak lahir. Hal ini membuat ruang kota menjadi semakin opresif bagi para migran karena ruang geraknya yang sempit untuk mengekspresikan identitas mereka.

Tulisan-tulisan poskolonial menolak tatanan kota yang menghomogenkan identitas dan menghilangkan hibriditas yang mendasari ruang kota tersebut. Dalam novel-novel poskolonial, salah satunya adalah The Kite Runner, identitas yang heterogen tidak saja dihadirkan namun juga menjadi alat resistensi yang kuat dalam ruang kota yang opresif. Tulisan-tulisan poskolonial menolak cara-cara kolonial yang menghadirkan wacana utopia untuk menarik subjek-subjek kolonial. Sebaliknya, wacana yang dihadirkan adalah kemunculan distopia yang merupakan lawan dari utopia, dimana realitas yang ada bertolak belakang dengan ide-ide utopia, menyuguhkan realitas yang ada di kota dan konsekuensi-konsekuensi yang harus diterima para migran di ruang kota. Konsekuensi tersebut seperti keharusan untuk 
bekerja keras, menerima perlakuan yang berbeda, bahkan penurunan gengsi dan derajat yang harus diterima di ruang kota kolonial yang tidak memedulikan identitas masing-masing individu yang membentuk kota tersebut sebagaimana yang juga digambarkan dalam novel The Kite Runner melalui tokoh Baba, Amir, Iqbal Taheri, dan beberapa tokoh dari Afganistan lainnya.

Tulisan-tulisan poskolonial tidak bersifat pesimis dalam menghadapi wacana kolonial, namun justru menghadirkan ruang kota yang menawarkan makna baru, dimana identitas heterogen dinegosiasikan melalui ruang-ruang publik yang mengonstruksi kota serta melalui pemindahan fokus dari ruang kota secara keseluruhan ke ruang yang lebih sempit, yakni ruang domestik, berupa hubungan personal antarindividu yang memberikan kebebasan dan menjadi strategi resistensi untuk mempertahankan identitas. Selain itu, tulisan poskolonial juga menghadirkan heterogenitas sebagai strategi meresistensi kolonisasi yang disebut strategi karnivalisasi. Dengan strategi karnivalisasi, identitas-identitas yang berbeda dimunculkan dalam satu ruang publik dan saling berinteraksi. Ini merupakan salah satu cara untuk meresistensi ruang kota yang berusaha menghomogenkan identitas melalui tatanannya.

\section{Daftar Pustaka}

Anker, Elizabeth S. 2011. Allegories of Falling and the 9/11 Novels. Oxford: Oxford University Press.

Ashcroft, Bill, dkk. 1995. The Postcolonial Studies Reader. New York: Routledge.

Hosseini, Khaled. 2011. The Kite Runner. London: Clays Limited.

Huthmacher, J. Joseph. 1974. A Nation of Newcomers. New York: Dell Publishing.

Mallik, Mary. 2010. Multicultural Ways of Knowing: Reading "The Kite Runner" in a Grade 11 Class. Ontario: Lakehead University. Diakses dari http://www.jstor.com pada 15 November 2013.

McLead, John. 2000. Beginning Postcolonialism. Manchaster: Manchaster University Press.

Upstone, Sara. 2009. Spatial Politics in the Postcolonial Novel. Surrey: Ashgate. 